УДК [94 : $622: 821.161 .2-94]$ (477.6) «18/19»

DOI: https://doi.org/10.33782/eminak2021.2(34).534

\title{
МЕМУАРИ ГІРНИЧИХ ІНЖЕНЕРІВ ДОНЕЦЬКОГО БАСЕЙНУ ДРУГОЇ ПОЛОВИНИ ХІХ - ПОЧАТКУ ХХ СТ.: ПРОФЕСІЙНИЙ АСПЕКТ
}

\author{
Олена Отземко \\ Донецький національний університет імені Василя Стуса (Вінниця, Україна) \\ e-mail: otzemko@gmail.com \\ ORCID: https://orcid.org/0000-0002-3164-1148
}

у статті розкрито інформаційний потенціал спогадів гірничих інженерів О. Ауербаха, О. Феніна, О. Терпигорєва, які працювали на рудниках Донбасу в другій половині XIX - на початку XX ст. Зосереджено увагу на професійному аспекті мемуарів, який включає технічні характеристики вугільних родовищ і рудників, питання організації гірничопромислового виробництва, розповіді про колег і підприємців з акцентом на професійних якостях, досить великі сюжети, присвячені шахтарям. Зазначається, що особливості біографій авторів і різні умови створення мемуарів спричинили відмінності у сприйнятті історичного контексту та віддзеркаленні спільних професійних сюжетів.

Ключові слова: Донбас, мемуари, гірничі інженери, рудник, шахтарі, вугільні родовища, промисловий розвиток

Історія Донбасу, як індустріального регіону, невід'ємно пов'язана з діяльністю технічної інтелігенції. Її еволюція, кількісна та якісна, відбувалася на тлі стрімкого зростання промислового потенціалу Донбасу. Друга половина XIX - початок XX ст. у цьому сенсі $є$ найважливішим періодом, під час якого відбувалася індустріальна модернізація регіону, а також формування інженерних кадрів гірничої сфери.

Зважаючи на це, мемуаристика гірничих інженерів, як представників технічної інтелігенції та вищої управлінської ланки вугільних підприємств, не втрачає актуальності щодо вивчення історії Донбасу другої половини XIX - початку XX ст. і на сучасному етапі.

Формування, склад, діяльність технічної інтелігенції Донбасу та Придніпров’я у другій половині XIX - на початку XX ст. на тлі розвитку промислового потенціалу регіону досліджено у дисертації П. Чорнобая 1 , монографіях Ю.Черкушиної та А. Перетокіна 2 , В. Кулікова3. Важливе значення для вивчення діяльності окремих інженерів мають біографічні дослідження4. Різні сторони промислового розвитку Донбасу розглянуто в узагальнюючих працях Г. Куромії ${ }^{5}$ Ю. Ніколайця6, колектив-

\footnotetext{
1 Чорнобай П. Формування технічної інтелігенції на Катеринославщині наприкінці XIX - на початку XX ст.: автореф. дис... канд. іст. наук: 07.00 .01 - історія України. Дніпропетровськ, 2010. 20 с.

2 Черкушина Ю., Перетокін А. Промисловий розвиток та інженерне підприємництво ДонецькоПридніпровського регіону (1880-1917рр.). Нац. гірн. ун-т. Дніпропетровськ: НГУ, 2013. 119 с.

3 Куліков В. Підприємства й суспільство в заводських і шахтарських поселеннях Донбасу та Придніпров'я в 1870-1917 рр. Харків: ХНУ імені В. Н. Каразіна, 2019. 388 с.

4 Черкушина Ю., Перетокин А. А.А. Ауєрбах - представитель регионального инженерного предпринимательства второй половины XIX - начала XX вв. // Гуманітарний журнал. 2009. № 1-2 (4041). С. 84-91; Розентретер Б. А. Александр Митрофанович Терпигорев. 1873-1959. Очерк жизни и деятельности. Москва: Наука, 1965. 184 с.

${ }^{5}$ Куромія Г. Свобода і терор в Донбасі: Українсько-російське прикордоння, 1870-1990-ті роки. Київ: «Основи», 2002. 510 с.
} 
ній монографії, присвяченій промисловим мономістам регіону7. Питання аналізу мемуаристики розглядаються у дослідженнях А. Тартаковського ${ }^{8}$, Дж. Старк․ Дотичною до теми є стаття Г. Швидько ${ }^{10}$.

Метою статті $є$ порівняльний аналіз інформаційного потенціалу спогадів гірничих інженерів 0. Ауербаха ${ }^{11}, 0$. Феніна ${ }^{12}, 0$. Терпигорєва ${ }^{13}$, які працювали на рудниках Донбасу у другій половині XIX - на початку XX ст. Спогади містять різнопланову інформацію, до якої зверталися автори згаданих вище розвідок з історії промислового розвитку регіону. Предметом дослідження є професійна складова змісту мемуарів. До аналізу також залучено спогади учасників революційних подій 19171921 рр. на Донбасі, які окрім революційного минулого, згадують, щоправда досить коротко, життя та роботу на шахтах регіону на початку XX ст.

Порівняльний аналіз інформаційних можливостей мемуарів гірничих інженерів грунтується на таких засадах. Ключова риса мемуаристки - зосередження автора на особистісних, суб'єктивних враженнях від пережитого та побаченого - у спогадах тісно переплітається з колективним виміром, позаяк мемуаристика виступає як результат не тільки індивідуальної, а й колективної (групової) пам'яті. Як зазначає М. Гальбвакс: «Погортайте мемуари будь-якого адміністратора, ділка, державного діяча: сумлінно виконавши свою функцію, він тепер викладає факти, якими були заповнені роки його праці та бурхливої діяльності, і це не стільки його власна історія, скільки історія певної соціальної групи - професійної чи світської» 14 .

Отже, спогади як мемуарне оповідання фактично будуються на декількох рівнях - особистому / автобіографічному, професійному, історичному, що зумовлює певну строкатість тексту. Професійний складник, особливо якщо людині притаманна активна професійна діяльність, часто переважає, спираючись на колективний дискурс, що відбиває соціально-професійну згуртованість ${ }^{15}$. Наслідком $є$ певна тематична заданість, структура таких мемуарів, «набір сюжетів».

\footnotetext{
${ }^{6}$ Ніколаєць Ю. Поселенська структура населення Донбасу: (етнополітичний аспект динаміки). Київ: ІПіЕНД ім. І. Ф. Кураса НАН України, 2012. 188 с.

7 Праця, виснаження та успіх: промислові мономіста Донбасу / М. Ільченко, К. Кузіна, В. Куліков, Т. Портнова, І. Склокіна, М. Студенна-Скруква, О. Стяжкіна. Львів: Центр міської історії, 2018. 244 c. URL: http://www.historians.in.ua/index.php/en/novi-knizhki/2435-volodimir-kulikov-irinasklokina-promislovi-monomista-risi-istoriya-obrisi-majbutnogo

8 Тартаковский А.Г. Мемуаристика как феномен культуры// Вопросы литературы.1999. № 1. C. 37-54.

${ }^{9}$ Stark J. British and American Diplomatic Memoirs as Factual Narratives: A Resource for the Linguistic and Cultural Analysis of the Specialised Domain of Diplomacy. ILCEA [Online]. 2018. № 31. Online since 06 March 2018, connection on 19 April 2019. URL: http://journals.openedition.org/ilcea/4680. DOI: $10.4000 /$ ilcea. 4680

10 Швидько Г.К. Катеринославщина початку XX ст. у спогадах вчених // Історія і культура Придніпров'я. Невідомі та маловідомі сторінки. 2014. Вип. 11. С. 68-82.

11 Ауэрбах А. Воспоминания о начале развития каменноугольной промышленности в России // Русская старина. 1909. Т. 138. № 6. С. 451-472; Т. 140. № 12. С. 546-562.

12 Фенин А. Воспоминания инженера: К истории общественного и хозяйственного развития России (1883-1906 гг.). Прага: Русский институт в Праге, 1938. 200 с.; Фенин А. Воспоминания инженера. II часть. URL: https://prozhito.org/memories?diaries=[8108]

13 Терпигорев А. Воспоминания горного инженера. Москва: Изд. АН СССР, 1956. 272 с.

14 Хальбвакс М. Социальные рамки памяти / пер. с фр. и вступ. статья С.Н. Зенкина. Москва: Новое издательство, 2007. С. 217.

15 Stark J. British and American Diplomatic Memoirs as Factual Narratives... (7).
} 
Ще одна суттєва особливість спогадів як різновиду мемуаристики - часова дистанція між подіями та створенням, яка може сягати декількох десятиліть, що істотно позначається на характері висвітлення подій. Під впливом життєвого досвіду, зміни становища у суспільстві, професії, досить часто політичної ситуації (ідеологічні установки, історична політика, цензура) відбувається певна аберація особистих поглядів автора на минуле. Тож мемуарист потрапляє у залежність від поглядів, сучасних написанню мемуарів 16.

3 огляду на сказане вище відзначимо спільні риси біографій авторів обраних для аналізу спогадів. Усі вони мали вищу інженерну освіту, закінчивши СанктПетербурзький гірничий інститут. Усі мали практичний досвід розвідки вугільних родовищ і роботи на вугільних рудниках Донбасу. О. Ауербах, який стояв у витоків гірничопромислової справи регіону, в 70-ті pр. XIX ст. займався розвідкою та будівництвом шахт Рутченківського, Курхівського та суміжних з ними вугільних родовищ. О. Фенін пропрацював на вугільних рудниках Донбасу з 1890 до 1907 рр. (Рутченківський № 19, Вознесенський П.О. Карпова, Макіївський І.Г. Іловайського, «Вєровський», «Максимівський»). О. Терпигорєв у 1895-1900 рр. займався розвідкою покладів залізної руди і вугілля, а також проєктуванням та управлінням рудниками М.П. Пастухова та його синів ${ }^{17}$.

Загалом, біографії всіх авторів, попри відмінності, особливо після 1917 р., до кінця життя пов'язані з гірничою справою. Всім притаманна активна професійна діяльність. О. Ауербах долучився до розробки ртутних родовищ Донбасу, консультував землевласників, які будували шахти й обладнували рудники, а також був одним із засновків 3'їзду гірничопромисловців Півдня Росії, у роботі якого брав участь до кінця життя. Від активної підприємницької діяльності він відійшов після 1907 р. О. Фенін також був активним членом 3'їзду гірничопромисловців (заступником голови Ради з'їзду), брав участь в управлінні акціонерними товариствами, які експлуатували вугільні родовища Донбасу. Емігрувавши в 1919 р. до Європи, він продовжував займатися розвідкою корисних копалин, окрім того, викладав у Вищій гірничий академії в Пршимбрамі (Чехословаччина). О. Терпигорєв з 1900 р. займався викладацькою та дослідницькою діяльністю, зробивши після 1917 р. вдалу кар'єру авторитетного радянського науковця 18.

Усі твори є класичними спогадами, написаними на схилі життя, але час та обставини їхнього створення докорінно відрізняються, зважаючи на згадані відмінності біографій авторів. Спогади О. Ауербаха написані на початку XX ст., фактично «по гарячим слідам», відразу після завершення активної професійної діяльності й опубліковані у 1909 р. Автор не формулює мотивів, які спонукали його до написання мемуарів, але вони проглядаються у назві - «Воспоминания о начале развития каменноугольной промышленности в России». Настрій автора, що відбився в мемуарах, на нашу думку, досить точно описав О.Фенін, який вперше зустрівся 3 О.Ауербахом у 1910 р.: «...тоді, коли він як давній почесний член нашої Ради

\footnotetext{
16 Тартаковский А. Г. Мемуаристика как феномен культуры... С. 38.

17 Черкушина Ю., Перетокін А. Промисловий розвиток та інженерне підприємництво... С. 33-35; Фенин А. Воспоминания инженера... С. 6; Розентретер Б. А. Александр Митрофанович Терпигорев... С. 18, 19, 26-30.

18 Черкушина Ю., Перетокін А. Промисловий розвиток та інженерне підприємництво... С. 33-35; Фенин А. Воспоминания инженера... С. 6-7; Розентретер Б.А. Александр Митрофанович Терпигорев... С. 32-82.
} 
з'явився вперше серед нас, він вже відходив \{проте відходив ним без видимої тіні незадоволеності життєвим шляхом, який він пройшов»19.

О. Фенін писав свої мемуари, будучи активним діячем російської еміграції у Чехословаччині. Мета його оповідання, просякнутого ностальгією, описати характерні риси та особливості суспільного та промислового життя Донецького басейну періоду «великого промислового будівництва», до якого долучився автор ${ }^{20}$. Дійсний член АН СРСР О. Терпигорєв прагне «наскільки можливо наочно показати» важке капіталістичне минуле та передове соціалістичне сучасне, зокрема «старий і новий Донбас»21.

Система управління на вугільних підприємствах Донбасу другої половини XIX початку XX ст. складалася з таких ланок: нижча (десятники - підземні, наземні, які безпосередньо взаємодіяли з робітниками); середня (штейгери - керували окремими об'єктами); вища (директори, управителі рудників, інженери) ${ }^{22}$. За даними В. Кулікова у 1901-1915 рр. на 1000 працівників гірничих і гірничозаводських підприємств Півдня Росії припадало 3 інженери, 4 представники середньої та 24 представники нижчої ланки управління 23.

Зважаючи на те, що всі автори мали вищу інженерну освіту та були гірничими інженерами-практиками, представниками вищої управлінської ланки вугільних підприємств Донбасу, вагому частину їхніх спогадів становлять сюжети, що відбивають професійну діяльність - «професійні практики» 24.

По-перше, багато уваги приділено технічним характеристикам вугільних родовищ і рудників. О. Ауербах подає коротку характеристику вугільної справи Донбасу на початку 70-х рр. XIX ст., представленої невеликими рудниками глибиною до 30 сажнів, акцентуючи увагу на рівні їхнього технічного обладнання. Серед найкращих він називає Юзівський (сучасний Донецьк) і Корсунський (сучасна Горлівка) рудники. Спогади віддзеркалюють його діяльність не тільки як інженера, але й як підприємця: автор докладно описав обставини розвідки, перемовин з братами O. та I. Рутченками щодо оренди та придбання їхніх земель, закладку Рутченківської копальні, а також розвідку, пошук джерел фінансування та будівництво копальні в маєтку П. Карпова (згодом Вознесенська, Петровська копальні, сучасний Донецьк), згадав він і про власну вугільну справу, а також про те, що продовжував консультувати гірничопромисловців і під час роботи поза межами Донбасу 25.

Про Рутченківську копальню згадує і О. Фенін. На шахті № 19 він у 1891 р., відразу ж після закінчення гірничого інституту, працював старшим штейгером: $1000-$ 1200 робітників, глибина близько 100 сажнів (близько 200 метрів) і зношене обладнання. Варта уваги розповідь Феніна про роботу шахти у зимових умовах, коли шахтний стовбур вкривався кригою так, що кліть з гірниками іноді застрягала у кризі, зависаючи над проваллям 26.

\footnotetext{
19 Фенин А. Воспоминания инженера. II часть. URL: https://prozhito.org/memories?diaries=[8108]

20 Фенин А. Воспоминания инженера... С. 5-6.

21 Терпигорев А. Воспоминания горного инженера... С. 5-6.

22 Чорнобай П. Формування технічної інтелігенції на Катеринославщині наприкінці XIX - на початку ХХ ст.... С. 13-14; Куліков В. Підприємства й суспільство в заводських і шахтарських поселеннях... С. 101-102.

${ }^{23}$ Куліков В. Підприємства й суспільство в заводських і шахтарських поселеннях... С. 102.

${ }^{24}$ Stark J. British and American Diplomatic Memoirs as Factual Narratives... (2).

25 Ауэрбах А. Воспоминания о начале развития... 1909. Т. 138. № 6. С. 456-460, 471-472; Т. 140. № 12 . C. 546.

26 Фенин А. Воспоминания инженера... С. 46-48.
} 
Найбільше уваги О. Фенін приділяє технічним характеристикам Вєровського та Максимівського рудників. Вєровський рудник будувався одночасно з Петровським металургійним заводом (сучасне Єнакієве) Русько-Бельгійського Товариства та мав постачати завод коксівним вугіллям. Як пише Фенін: «Це була..., мабуть, єдина в моєму житті творча інженерна робота, здійснена від самого її початку і до кінця, від розвідки родовища, купівлі землі, побудови рудника та його запуску»27. Тож, цьому етапу своєї професійної діяльності автор приділив особливу увагу: він подає докладну характеристику родовища, обставини розвідки, спорудження, технічних новацій шахти потужністю 2 млн. пудів вугілля на місяць, констатуючи, що «у незайманому доти степу було споруджено рудник сучасного західноєвропейського типу» 28.

Директором Максимівського рудника (м. Кадіївка, Луганська область) О. Фенін працював у 1899-1906 рр., продовжуючи представляти справи рудника і після переїзду до Харкова. Власне повна самостійність у роботі, включно з реалізацією високоякісного вугілля та коксу, зацікавила інженера, попри технічну відсталість і бідність родовища. Автор з ентузіазмом розповідає про перші роки керування рудником, що являв собою сукупність дрібних копалень, розкиданих у степу ${ }^{29}$.

Найбільші за обсягом і докладністю технічних характеристик сюжети містять спогади О. Тепигорєва. Автор працював головою рудників Сулинського металургійного заводу, які належали родині Пастухових (Область Війська Донського, сучасна Ростовська область Росії). Через специфіку своєї діяльності він об'їздив весь Донбас, часто бував на рудниках в інших районах і мав уявлення про їхній устрій і діяльність. О. Терпигорєв проєктував нову шахту Пастухових у районі Берестовського рудника біля Юзівки та консультував їі будівництво. Працюючи у Катеринославському вищому гірничому училищі, він продовжував дослідження вугільних родовищ і рудників Донецького басейну. Результати цих досліджень були підсумовані у двох капітальних працях, виданих у 1905 і 1914 рp. ${ }^{30}$

У спогадах 0. Терпигорєва подана докладна технічна характеристика антрацитових і частково коксових рудників Донбасу: глибина, устрій (наземний і підземний), способи відкатки (транспортування здобутого вугілля під землею), рудничне обладнання, механізація виробництва. Загалом, автор наголошує, що незважаючи на обсяги видобутку вугілля, на Донбасі початку XX ст. було чимало дрібних, погано обладнаних шахт («мишоловки»). Механізація - використання врубових машин, парових та електричних підйомних машин, насосів, вентиляторів, відбійних молотків, перфораторів - була характерна для великих шахт. Як приклади автор згадує Голубовський, Ірмінський рудники, Вєровський рудник Русько-Бельгійського товариства, шахту «Нова Смолянка» глибиною 700 м, яка належала Новоросійському товариству та поставляла металургійному заводу Юза «відмінний кокс»31.

Відзначимо, що О. Терпигорєв у спогадах наголошує на невигідності механізації, зокрема застосування врубових машин, для власників шахт. Ба більше, він стверджує, що «машини, виписані з-за кордону», абсолютно не підходили для місцевих рудників, і наводить приклад з невдалим використанням врубової машини «Дай-

\footnotetext{
27 Ibid. C. 69.

28 Ibid. C. 69-79.

29 Фенин А. Воспоминания инженера... С. 91-93, 110.

30 Розентретер Б. А. Александр Митрофанович Терпигорев... С. 27, 44-65.

31 Терпигорев А. Воспоминания горного инженера... С. 41-44, 49, 60-73, 135-137.
} 
монд». Водночас Б. Розентретер у біографії вже академіка О. Терпигорєва покликається на його дослідження початку ХХ ст., в яких автор наголошує на разючому ефекті застосування машин цього типу та рекомендує їхнє використання 32 .

У мемуарах 0. Терпигорєва докладно описана ще одна сторона шахтних реалій вибухи газу на рудниках. Були періоди, коли вони траплялися мало не щомісяця, позаяк вугільні пласти Донецького басейну відрізняються підвищеною газонасиченістю. Керівництво ж підприємств в умовах жорсткої конкуренції було зацікавлене передусім у прибутках, техніка безпеки розглядалася як щось другорядне. Інженер брав участь у розслідуваннях аварій як член урядових комісій. За його свідченнями, у 1901-1906 рр. на шахтах Донбасу тільки через використання гірниками так званих «відкритих ламп» (масляний світильник з відкритим полум'ям) сталося 13 сильних вибухів ${ }^{33}$. Терпигорєв брав участь й у розслідуванні причин аварії 1908 р. на Риковській (Макарьєвській) копальні (сучасний Донецьк), яка забрала життя 270 шахтарів. Тут він не наводить технічних деталей, але передає враження очевидців і наголошує на повній безпорадності адміністрації, представники якої навіть не могли знайти плану шахти. Він також відзначає примітивний рівень рятувальної служби ${ }^{34}$.

0. Фенін та О. Терпигорєв чимало уваги приділяють питанням організації гірничопромислового виробництва, окреслюють повноваження та роль управлінців різних ланок: директора, управителя рудника, штейгерів, десятників, завідувачів шахтних механізмів, завідувачів коксових печей, артільників 35 . За словами 0. Феніна, він як директор мав бути в курсі та керувати всією роботою рудника, особливо видобутком вугілля, її розмірами, собівартістю, заробітною платою робітників; поза межами рудника треба було вирішувати питання вигідного продажу вугілля, включно з вчасним забезпеченням вагонами для вивозу, постачанням рудника коштами, велике значення мали взаємини з іноземними власниками рудників, спілкування 3 окружними гірничими інженерами та маркшейдерами ${ }^{36}$. О. Терпигорєв докладно описав роботу забійників, зарубників, саночників, робітників інших спеціальностей і т.ін. ${ }^{37}$

Інтереси 0. Ауербаха як інженера та підприємця були ширшими за гірничопромислове виробництво. У невеликих за обсягом мемуарах чимало уваги приділено проблемам будівництва залізниць як нагальної потреби для розвитку промисловості, зокрема гірничої, на Донбасі та Придніпров"ї («Півдні Росії»). Це стало одним зі спонукальних мотивів створення 3'їзду гірничопромисловців Півдня Росії, про що докладно розповідає автор 38 . Окремий розділ роботи 3'їзду присвятив О. Фенін, наголошуючи на тому, що головною його метою було «розширення ринків збуту вугілля», переважно, через «боротьбу за залізниці», вивчення можливостей експорту вугілля. Серед важливих результатів діяльності 3’їзду автор називає відкриття

\footnotetext{
32 Терпигорев А. Воспоминания горного инженера... С. 72; Розентретер Б. А. Александр Митрофанович Терпигорев... С. 53-54.

33 Терпигорев А. Воспоминания горного инженера... С. 122; Праця, виснаження та успіх: промислові мономіста Донбасу... С. 172.

34 Терпигорев А. Воспоминания горного инженера... С. 123-126.

35 Фенин А. Воспоминания инженера... С. 115, 116; Терпигорев А. Воспоминания горного инженеpa... С. 64-67, 70.

36 Фенин А. Воспоминания инженера... С. 99-100, 115-116.

37 Терпигорев А. Воспоминания горного инженера... С. 65-67.

38 Ауэрбах А. Воспоминания о начале развития... Т. 138, № 6. С. 465-469.
} 
мережі рятувальних станцій, а також Макіївської випробувальної станції та школи рятувальників, створення детальної геологічної карти Донбасу (доручено Л.І. Лутугіну), відкриття бібліотеки та Горно-Геологічного музею, видання наукових праць у галузі гірничої справи (про це згадує і О. Тепигорєв) ${ }^{39}$.

Спогади інженерів, окрім технічних та організаційних деталей виробництва, віддзеркалюють емоційну складову їхньої професійної діяльності, яка є реакцією на умови роботи, успіхи та невдачі. Зокрема, мемуари О. Ауербаха просякнуті духом енергійного, часто ризикового підприємництва. О. Фенін відзначає, що матеріальне становище його з розвитком кар'єри постійно покращувалося, це дало змогу навіть купити невеликий маєток у Полтавській області. Водночас, перші п'ять років на шахтах Донбасу (зокрема Рутченківському, Вознесенському, Макіївському рудниках) він згадує як «важкий кошмар»: голий степ, шахтні пейзажі, неосвічена місцева публіка, одноманітність сірого життя, яка багатьох рудничних інженерів спонукала до пияцтва: «Рудники досить слабко пов'язані з центрами, відсутнє навіть близьке сусідство. Рудничне товариство перебуває у важкій тузі, розважаючись ходінням у гості на горілку і карти». Певне задоволення від роботи автор відчув, лише набувши професійного досвіду, авторитету на посадах управителя та директора рудника ${ }^{40}$. Втім, тема замкненості, в'ялості, нудьги провінційного життя в «медвежьих углах» і далі присутня на сторінках його спогадів 41.

У О. Терпигорєва знаходимо лише окремі згадки про умови роботи інженера на руднику. Незважаючи на критику власників щодо варварських умов праці та побуту шахтарів, автор визнає, що молодий інженер навряд міг знайти такі «прекрасні умови» роботи, як у М.П. Пастухова: 150 руб. зарплати, премії, казенна квартира та власний виїзд. Така увага, передусім, до матеріальних умов зрозуміла з огляду на те, що автор з часів навчання в реальному училищі змушений був самостійно заробляти на навчання та проживання. Водночас, показовим $\epsilon$ і те, що через три роки роботи на посаді управителя рудника Терпигорєв, попри значно меншу зарплату, перейшов на викладацьку роботу до Катеринославського вищого гірничого училища 42 .

Важливим елементом професійного дискурсу спогадів гірничих інженерів $\epsilon$ розповіді про колег і підприємців. Це люди, з якими автори працювали або зустрічалися в процесі роботи, тому сюжети або згадки про них містять, окрім особистих, професійні характеристики. Чимало уваги приділено власникам вугільних підприємств, з якими гірничі інженери часто співпрацювали, починаючи від розвідки родовища до управління побудованим рудником і реалізації продукції. Завдяки спогадам маємо не просто згадки, а низку портретів перших підприємців Донбасу. Вони поєднують особисті та професійні якості, на які мемуаристи звертають особливу увагу: могутній підприємець С.С. Поляков, підприємливий та окрутистий поміщик П.О. Карпов, «справжній барин», водночас «здібний адміністратор і спритний комерційний ділок» Д.І. Іловайський, родина шахтовласників Пастухових ${ }^{43}$.

\footnotetext{
39 Фенин А. Воспоминания инженера. II часть; Терпигорев А. Воспоминания горного инженера... C. 134.

${ }^{40}$ Ауэрбах А. Воспоминания о начале развития... Т. 138, № 6. С. 471-472; Фенин А. Воспоминания инженера... С. 45-47, 60-62.

41 Фенин А. Воспоминания инженера... С. 113, 134, 146.

42 Терпигорев А. Воспоминания горного инженера... С. 57, 78, 80.

43 Ауэрбах А. Воспоминания о начале развития... Т. 138. № 6. С. 463-465, 471-472; Фенин А. Воспоминания инженера... С. 60-61; Терпигорев А. Воспоминания горного инженера... С. 75.
} 
У спогадах О. Ауербаха маємо тільки прізвища гірничих інженерів, з якими він співпрацював у складі 3'їзду гірничопромисловців у другій половині XIX ст. Окремо, як «розумну й талановиту людину» автор згадує інженера П.М. Горлова 44.

Найбільше уваги колегам приділив О. Фенін. У його мемуарах постає ціла плеяда гірничих інженерів, з якими йому довелося працювати впродовж кар'єри на шахтах Донбасу та у складі 3'їзду гірничопромисловців. Автор, окрім розповіді про спільну роботу, присвятив їм окремі розділи в обох частинах своїх мемуарів. Описуючи характери, особисте життя, він докладно зупиняється на професійній діяльності колег-інженерів. Маємо цікаві сюжети про відомого геолога Л.І. Лутугіна, членів Ради 3'їзду гірничопромисловців Л.Г. Рабіновича та Б.М. Соколова, репресованих за «Шахтинською справою» й ін. Є сюжет і про О. Ауербаха 45.

Зовсім не пише про своїх колег О. Тепигорєв, ймовірно тому, що частина їх була репресована, а чимало опинилося в еміграції, про що докладно розповів О. Фенін.

Значне місце у мемуарах усіх без винятку авторів відводиться шахтарям. У спогадах 0. Ауербаха наголошується: «3 початком розвитку кам'яновугільної справи на півдні Росії, там з'явився особливий клас людей, так званих «шахтарів», тобто тих, що працюють у шахтах». Це були переважно селяни з середніх російських губерній, але чимало було волоцюг, біглих каторжників, тих, хто спився, - колишні купці, священники, поліцейські тощо ${ }^{46}$. 0. Ауербах, 0. Фенін і О. Терпигорєв досить докладно зупиняються на особливостях шахтарської праці, іï організації, відзначаючи варварські умови («вільна каторга»), зловживання підрядників та артільників. Головною проблемою шахтарського життя вони вважали пияцтво, яке здатне було зупинити роботу копальні на 2-3 дні. Відзначимо й те, що О. Фенін, на відміну від 0. Терпигорєва, провину за важкі умови життя та пияцтво частково покладає на самих шахтарів, виправдовуючи власників підприємств, які, за переконанням автора, прагнули налагодити нормальне життя робітників. На підтвердження своїх поглядів він наводить приклади вдалої кар'єри окремих шахтарів, які «доросли» до посади майстра або стали артільниками, десятниками, забезпечивши собі та своїй родині пристойні умови життя: «Шахтар, що вибився в «люди», став майстром-десятником, машиністом, забійником або кріпильником, - часто і звичайний різнороб, але стійка, така, що вміє триматися, людина, - шахтарська меншість, робоча духовна аристократія рудника, - швидко змінювався і зовні ...3 учорашнього мужика викристалізовувався промисловий робітник» 47.

О. Тепигорєв пише про використання дитячої праці на шахтах Донбасу, про що не згадують інші інженери. Формально на шахту допускалися підлітки не молодше 16 років, але на практиці починали працювати з 13-ти років, на що начальство не звертало уваги. Діти, зокрема дівчата, працювали переважно на допоміжних роботах ${ }^{48}$. Відомості О. Терпигорєва підтверджують у своїх спогадах, написаних до ювілейних дат революції 1917 р., «старі більшовики». Більшість їхніх спогадів звичайно присвячена революційним подіям, але дехто подає автобіографічну інформацію. Ф.Соколов почав працювати з 13-ти років - на Вознесенській копальні був

\footnotetext{
44 Ауэрбах А. Воспоминания о начале развития... Т. 138. № 6. С. 462-464.

45 Фенин А. Воспоминания инженера... С. 25-26, 53, 70, 119-146; Фенин А. Воспоминания инженера. II часть.

46 Ауэрбах А. Воспоминания о начале развития... Т. 140. № 12. С. 547, 549, 551.

47 Ауэрбах А. Воспоминания о начале развития... Т. 140. № 12. С. 551-552; Терпигорев А. Воспоминания горного инженера... С. 60-70; Фенин А. Воспоминания инженера... С. 48-51, 53-59, 117. 48 Терпигорев А. Воспоминания горного инженера... С. 78.
} 
лампоносом, з 15-ти років - коногоном, кріпильником; з 11-ти років працювали І. Людников (Юзівка) - на вибірці породи (таких «робітників» називали «копченка» через те, що вони були чорні від вугільного пилу), К. Плахова - на рудничній мийці (Берестово-Богодухівський рудник) ${ }^{49}$.

Усі автори констатують страшні умови життя шахтарів, що є відомим фактом. Цікаве пояснення відмови гірників переходити у нові побудовані для них казарми наводить О. Ауербах: не хотіли звикати до гарних умов життя, які б втратили у випадку звільнення ${ }^{50}$.

Загалом, всі мемуаристи неодноразово наголошують на справедливому ставленні до робітників тих копалень, де вони працювали. О.Ауербах, розповідаючи про піклування про гірників - організацію дешевих крамниць, побудову житла, стверджує, що на межі XIX-XX ст. землянки відійшли в минуле, всюди є школи та лікарні (!)51. Утім, у спогадах старого (неписьменного у 1957 р.) шахтаря Н. Коломійцева читаємо, що він народився у «скотському сараї» на БерестовоБогодухівському руднику, так само спадковий гірник А. Прокоф'єв називає місцем свого народження «балаган» (землянка) на шахті Пастухівка (згаданих вище шахтовласників Пастухових). А теж неписьменна К. Плахова розповідає, що таке «балаган»: кімната близько 16 кв. м із земляною підлогою, в якій мешкала родина з 9ти осіб52.

О. Фенін, присвятивши досить значний фрагмент сюжету взаємин гірничих інженерів і шахтарів, малює їх як «форму товарищеского сослужения», яка грунтувалася на засадах певної взаємоповаги ${ }^{53}$. Відчувається прагнення у певний спосіб романтизувати відносини з робітниками. Водночас, така форма відносин керівників підприємств зі своїми робітниками, яка трактується сучасними дослідниками як патерналістська модель, мала місце у заводських і шахтарських поселеннях не тільки Донбасу54. Втім, маємо відгуки іншої сторони щодо взаємин інженера Феніна та гірників. Г. Куромія посилається на листівку Спілки гірничозаводських робітників 1903 р., в якій вони вимагають звільнення «інженера Феніна», який ставиться до робітників гірше, ніж до тварин 55 .

На завершення відзначимо спільні риси, які складають тло спогадів О. Ауербаха, 0. Феніна, О. Терпигорєва: гарна освіта, професіоналізм, ерудиція, енергійність, підприємливість, прагнення нового.

Спогади містять значну за обсягом інформацію професійного характеру, яка охоплює технічні характеристики вугільних родовищ і рудників, питання організації гірничопромислового виробництва, розповіді про колег і підприємців з акцентом на професійних якостях, досить великі сюжети, присвячені шахтарям. Ця інформація переплітається з особистісним сприйняттям реалій промислового регіону, який швидко розвивався, зокрема умов роботи, побуту, взаємин з колегами та гірниками.

\footnotetext{
49 Державний архів Донецької області (далі - ДАДО). Ф. Р-2858. Оп. 7. Спр. 1. Арк. 1; Оп. 15. Спр. 4. Арк. 1; Ф. П-533. Оп. 1. Спр. 15. Арк. 7-13.

50 Ауэрбах А. Воспоминания о начале развития ... Т. 140. № 12. С. 557-558.

${ }^{51}$ Ауэрбах А. Воспоминания о начале развития... Т. 140. № 12. С. 559.

52 ДАДО. Ф. Р-2858. Оп. 3. Спр. 1. Арк. 1; Оп. 7. Спр. 1. Арк. 1.

53 Фенин А. Воспоминания инженера... С. 48-50.

54 Праця, виснаження та успіх: промислові мономіста Донбасу...

55 Куромія Г. Свобода і терор в Донбасі... С. 83; Чего мы требуем (1903). Летопись революции. 1923. № 2. C. 240-242.
} 
Особливості біографій і відзначені вище умови створення мемуарів спричинили відмінності у сприйнятті історичного контексту та віддзеркаленні спільних професійних сюжетів. О. Ауербах зосереджується на власній професійної діяльності, 3 огляду на що розповідає про шахти, на яких працював, та людей, з якими спілкувався. О. Фенін, окрім професійної діяльності, найбільше уваги приділяє людям, 3 якими йому довелося працювати. Для нього це частина втраченого світу. У спогадах 0. Терпигорєва абсолютно переважають технічні сюжети. Наскрізною лінією його мемуарів $\epsilon$ порівняння дореволюційного та соціалістичного Донбасу. Він багато уваги приділяє проблемам і негативним сторонам роботи вугільних підприємств, зачіпає такі питання, яких його колеги не торкалися.

Водночас, всім авторам притаманне розуміння значущості своєї роботи та відчуття причетності до потужного промислового будівництва, що і стало мотивом написання мемуарів.

\section{REFERENCES}

Auerbakh, A. (1909). Vospominaniia o nachale razvitiia kamennougolnoi promyshlennosti v Rossii [Memories of the beginning of the development coal industry in Russia]. Russkaia starina, Vol. 138 (6), 451-472; Vol. 140 (12), 546-562 [in Russian].

Cherkushina, Yu. \& Peretokin, A. (2009). A.A. Auerbakh predstavitel regionalnogo inzhenernogo predprinimatelstva vtoroi poloviny XIX - nachala XX vv. [A.A. Auerbach is a representative of the regional engineering entrepreneurship of the second half of the $19^{\text {th }}-$ early $20^{\text {th }}$ centuries]. Gumanitarnyi zhurnal, 1-2 (40-41), 84-91 [in Russian].

Cherkushyna, Yu. \& Peretokin, A. (2013). Promyslovyi rozvytok ta inzhenerne pidpryiemnytstvo Donetsko-Prydniprovskoho rehionu (1880-1917 rr.) [Industrial development and engineering entrepreneurship of the Donetsk-Prydniprovsk region (1880-1917)]. Dnipropetrovsk: NHU [in Ukrainian].

Chornobai, P. (2010). Formuvannia tekhnichnoi intelihentsii na Katerynoslavshchyni naprykintsi XIX - na pochatku XX st. [The Formation of Science Intelligentsia in Katerinoslavschyna at the End of the $19^{\text {th }}$ early $20^{\text {th }}$ century]. (Extended abstract of Candidate's thesis). Dnipropetrovsk [in Ukrainian].

Fenin, A. (1938). Vospominaniia inzhenera. K istorii obshchestvennogo i khoziaistvennogo razvitiia Rossii (1883-1906 gg.) [Memoirs of an Engineer: On the History of Social and Economic Development of Russia (1883-1906)]. Praga: Russkii institut v Prage [in Russian].

Fenin, A. (N.d.). Vospominaniia inzhenera. Chast II [Memories of an Engineer. Part II]. Retrieved from https://prozhito.org/memories?diaries=[8108] [in Russian].

Ilchenko, M. \& etc. (2018). Pratsia, vysnazhennia ta uspikh: promyslovi monomista Donbasu [Labor, exhaustion and success: industrial monocities of Donbass]. Lviv: Tsentr miskoi istorii [in Ukrainian].

Khalbvaks, M. (2007). Sotsialnye ramki pamiati [Social frameworks of memory]. Moskva: Novoe izdatelstvo [in Russian].

Kulikov, V. (2019). Pidpryemstva i suspilstvo v zavodskykh i shakhtarskykh poselenniakh Donbasu ta Prydniprovia v 1870-1917 rr. [Промисловий розвиток та інженерне підприємництво ДонецькоПридніпровського регіону (1880-1917 pp.)]. Kharkiv: KhNU imeni V.N. Karazina [in Ukrainian].

Kuromiia, H. (2002). Svoboda i teror v Donbasi: Ukrainsko-rosiiske prykordonnia, 1870-1990-ti roky [Freedom and Terror in the Donbas: A Ukrainian-Russian Borderland, 1870s-1990s]. Kyiv: «Osnovy» [in Ukrainian].

Nikolaiets, Yu. (2012). Poselenska struktura naselennia Donbasu: (etnopolitychnyi aspekt dynamiky) [Settlement structure of the population of Donbass: (ethnopolitical aspect of dynamics)]. Kyiv [in Ukrainian].

Rozentreter, B. (1965). Aleksandr Mitrofanovich Terpigorev. 1873-1959. Ocherk zhyzni i deiatelnosti [Alexander Mitrofanovich Terpigorev. 1873-1959. Essay on life and work]. Moskva: Nauka [in Russian].

Shvydko, H. (2014). Katerynoslavshchyna pochatku XX st. u spohadakh vchenykh [Katerynoslavshchyna early XX century in the memoirs of scientists]. Istoriia i kultura Prydniprovia. Nevidomi ta malovidomi storinky, 11, 68-82 [in Ukrainian].

Stark, J. (2018). British and American Diplomatic Memoirs as Factual Narratives: A Resource for the Linguistic and Cultural Analysis of the Specialised Domain of Diplomacy. ILCEA, 31. Retrieved from http://journals.openedition.org/ilcea/4680. DOI: 10.4000/ilcea.4680 
Tartakovskii, A. (1999) Memuaristika kak fenomen kultury [Memoiristics as a cultural phenomenon]. Voprosy literatury, 1, 37-54 [in Russian].

Terpigorev, A. (1956). Vospominaniia gornogo inzhenera [Memoirs of a mining engineer]. Moskva: Izd. AN SSSR [in Russian].

\section{Olena Otzemko}

(Vasyl' Stus Donetsk National University, Vinnytsia, Ukraine)

e-mail: otzemko@gmail.com

ORCID: https://orcid.org/0000-0002-3164-1148

\section{Donetsk Basin Mining Engineers Memoirs of Second Half of $19^{\text {th }}-$ Early $20^{\text {th }}$ Century: Professional Aspect}

The information potential of the memoirs of mining engineers 0.Auerbach, O. Fenin, 0 . Terpyhoriev, who worked at the mines of Donbas in the second half of the $19^{\text {th }}-$ early $20^{\text {th }}$ century is analyzed in the paper.

Memories as memoirs, in fact, are constructed on several levels: personal/autobiographical, professional, historical. The professional component, especially if a person is characterized by active professional activity, often prevails, based on collective discourse. Under the influence of life experience, changes in society, profession, political situation, a certain aberration of the author's personal interpretation of the past takes place. Therefore, the memoirist becomes dependent on the views contemporary to the writing of memoirs.

It is noted that the analyzed memoirs contain a sizeable amount of professional information, including technical characteristics of coal deposits and mines, the organization of mining, information about colleagues and entrepreneurs with an emphasis on professional qualities, rather long stories about miners. This information is intertwined with the personal interpretation of the realities of rapidly developing industrial region, in particular, working and living conditions, relationships with colleagues and miners.

Peculiarities of biographies and conditions of memoirs creation caused differences in interpretation of the historical context and description of common professional situations. 0 . Auerbach focuses on his professional activities, thus telling about the mines he worked at and the people he interacted with. In addition to his professional activity, O. Fenin, along with describing his professional activities, pays much attention to the people he had to work with. For him, it is part of a lost world. In 0. Terpyhoriev's memoirs, technical information absolutely prevails. The prevailing theme of his memoirs is a comparison of pre-revolutionary and socialist Donbas. At the same time, all authors have an understanding of their work significance and a sense of involvement in powerful industrialized construction, which became the motive for writing memoirs.

Keywords: Donbas, memoirs, mining engineers, mine, miners, coal deposits, industrial development 